の撮影の間に撮影対象が移動するとその部位はサブトラクションさ れずアーチファクトとなる。. 今回，このアーチファクトをミスマッ チとし，実際の読影に際しその影響の程度を放射線科医の主観的立 場から評価したので報告する。

【方法】TWO SHOT法によるデュアルエネルギーサブトラクション法 にて撮影した臨床例 1150 例の軟部組織画像を放射線科専門医 2 名が 読影し，以下の 4 段階にて評価を行った。肺野は右肺野と左肺野に 分けて評価し，画質評価は肺野を観察する場合に障害となるミス マッチの大小で判定した．評価の基準は 4 段階である. 最も良いも のから，ミスマッチのほとんどない場合にエクセレント，ミスマッ チが少しある場合にグッド，大きなミスマッチがあるものの $50 \%$ 以 上の肺野で観察良好な場合にアクセプタブル，50\%以上の肺野でミ スマッチにより観察不良な場合にノットアクセプタブルとした。

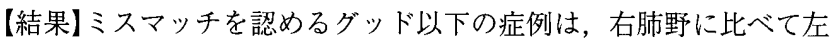
肺野に有意に多い結果となった。これは，その殆どが心臟の拍動に よるモーションアーチファクトであった

【考察】心臓の拍動による左肺野のミスマッチは，心電同期をかけて 撮影すればある程度減弱させる可能性がある。また，ワーピング等 の画像処理等も有効と考えられる.

24 TWO SHOT法によるデュアルエネルギーサブトラクション の基礎的検討一胸部腫瘤陰影の検出能の評価一

大阪大学大学院 ·医学系研究科保健学専攻医用物理工学講座 田頭裕之，村瀬研也

国立大学法人愛媛大学医学部附属病院・放射線部 山内 聡 別府稚子，吉本政弘，望月輝一

【目的】TWO SHOT法によるデュアルエネルギーサブトラクション法 は0.2秒間に高圧，低圧の各条件にて 2 回の撮影を行い，通常の胸部 画像, 骨陰影を除した軟部組織画像, 骨画像が得られる. 1 報にて 報告したシステム感度200にて撮影した臨床例を用いて，本法使用 による胸部腫瘤陰影の検出能向上の有無をROC(連続確信度法)に評 価したので報告する，尚，本装置での臨床撮影に当たり，患者様に は十分なインフォームドコンセントを行い承諾を得, 本院倫理委員 会の承諾も得ている。

【方法】1150例の内，CTによる画像診断を確定診断とした胸部腫瘤陰 影を含む50例，陰影無し50例を用い，経験年数15年以上の放射線科 医 6 名が読影を行い，ROC(連続確信度法)評価を行った。確信度記 入に際しては, 最初通常の胸部画像のみの読影で記入し, 続いて軟 部組織画像を読影後記入する方法をとった.

【結果】放射線科医 6 名すべての評価結果において，軟部組織画像を 用いた方が，AZ值が有意に高く本法の臨床での有用性が期待出来る 結果となった。

【考察】今後, 他の症例 (GGO, 網状影) 等の検出能も検討したい。 た, システム感度を変化させて, 被曝低減がどの程度まで可能か検 討したい.

\section{5 発表取り下げ}

26 脳萎縮測定における灰白質抽出方法について一SPM2 を使用 した自動抽出法の検討一

医療法人医仁会中村記念病院·放射線部 大友厚志，高橋正昭

山岸 仁

中村記念病院·脳神経外科 中川原譲二, 中村博彦

【目的】高齢化社会を迎え，アルッハイマー氏病などの認知障害が関 心を呼ぶようになっている。しかしながら画像診断の関与は必ずし も高くなく，脳核医学において頭頂～側頭葉領域の脳血流低下を指 摘することが確定診断の一つとして認められているだけで, MRIで は脳萎縮の程度を指摘することでその関与は高くない. その原因と
して脳萎縮の評価が客観的でないことが挙げられる。欧米では VOXEL BASED MORPHOMETRY (VBM)を使って脳萎縮の程度を客 観的評価することが行われはじめられている．灰白質の抽出には， SPM2 を使用してMRI画像より自動処理で行われているが，その灰 白質抽出の精度が求められる. 今回, 3D-T1WIをMPRで任意のスラ イス厚にTRANSAXIAL画像を作成し, normalization-segmentation処 理における灰白質抽出の精度について検討した。

【結果】スライス厚が大きいと標準脳への正規化 (normalization)がPVE を伴って補間されるため, segmentationにおける灰白質抽出の過大評 価を認めた. SPM：Statistical Parametric Mapping

27 肺CT-nodule検出CADにおけるSSPS解析の有用性 京都市立病院·放射線技術科 宮井 明，小倉明夫，前田富美恵 洛和会音羽病院 菊元力也

京都工芸綫維大学 中森伸行

【目的】従来へリカルCTでは, raw dataからスライス厚に応じた画像 再構成ピッチで再構成を行っている. CADもそのように再構成され た画像(一般的にフイルミングされる画像)を用いて処理を行ってい るのが現状である. 今回われわれは, 同一のraw dataを用い, 画像再 構成ピッチを小さくする手法 (Slice selected phase shift analysis, SSPS) による, CADの検出能の向上に対して, 検討を行った。

【方法】Noduleのある胸部CT画像10例を用い, 通常の再構成で得た画 像と, SSPSを使用した再構成画像を, それぞれ 5 名の観察者で視覚 評価を行い, Noduleの検出能を比較した. 加えて, 各々の画像に対 してCADを施行し，検出可能であったNoduleの比較を行った．

【結果】SSPSを使用することにより, 通常の再構成ピッチでは得られ なかったnoduleが新たに検出可能となった。またCADにおいても， SSPS処理を行った後の解析では, noduleの検出能が増加した. ま た, 今回の研究により, 連続的な各スライスでの目的物の信号強度 の変化から, 目的物の形状の推測が可能になることが示唆された.

28 動態画像患者認識システムの特徴量データマイニングによる判 別モジュールの最適化

静岡県立こども病院・放射線科 土屋裕一郎

名古屋大学・医学部保健学科 小寺吉衞

【目的】胸部動態撮影画像を対象とした患者認識システムにおける判 別モジュールの最適化を目的とする。

【方法】本研究で使用する患者認識システムは, 動態画像を運動解析 し作画されたカラー静止画像の有する類似性と唯一性を評価し，患 者の認識を行うシステムである，類似性を評価する特徵量として， 相互相関係数・およびその標準偏差・エークリット距離・マハラノ ビス距離が選択された。また, 判別手法として, 人工ニューラル ネットワーク・判別分析により求められた線形判別式・マハラノビ 又距離の距離判定・主成分分析により得られた第一, 第二主成分の 符号判定を選択した，学習用データにはI.I.システムによって撮影さ れた 5 名のボランティアによる左下肺野の画像が, 性能評価用デー 夕には, 動画対応FPDシステムによって撮影された 8 名のボラン ティアによる胸部画像が使用された。それぞれの特徽量と判別手法 について感度・特異度を評価し, 判別モジュールの再構築を行っ た.

【結果】採用する特徽量と判別手法の違いにより, 感度と特異度の差 異が認められた，マハラノビス距離判定により感度100\%，4つの特 徵量を使用したニューロによる判別によって特異度 $100 \%$ が得られ た. 両判別方法を直列に構成し, システムを再構築することによっ て, 性能評価用デー夕 8 人分 120 パターンすべての組み合わせを正 しく判別できた．また, 判別の決定にマハラノビス距離が大きく寄 与していることが，主成分分析によって明らかになった。

【結語】特徴量のデータマイニングにより効率的なデー夕活用が可能 